\title{
İyonlaştırıcı Radyasyonun Hücresel ve Moleküler Düzeydeki Etkileri
}

\author{
Cellular and Molecular Effects of Ionizing Radiation
}

\author{
Yaşar Aysun MANíSALIGíL ${ }^{1^{*}}$, Ayşegül YURT ${ }^{1,2}$ \\ ${ }^{1}$ Dokuz Eylül Üniversitesi Sağllk Hizmetleri MYO Tıbbi Görüntüleme Teknikleri Programı, İzmir \\ ${ }^{2}$ Dokuz Eylül Üniversitesi Sağllk Bilimleri Enstitüsü Medikal Fizik AD, İzmir
}

ÖZ

Hastalıkların erken tanı ve tedavisinde, iyonize radyasyon içeren görüntüleme yöntemleri önemli rol oynarlar. Tanı ve tedavide, hastaya uygulanacak radyasyon dozunun mümkün olduğunca az tutulması ve radyasyondan koruyucu önlemler alınmasına rağmen hastada radyasyon hasarı oluşma olasılığı bulunmaktadır. Bu nedenle düşük ve/veya yüksek doz radyasyon uygulamaları, hücrede biyokimyasal ve moleküler sinyal yolaklarını aktive ederek, hücresel düzeyde etkiler oluşturmaktadır. Günümüzde radyasyon içeren uygulamaların sıklığı ve teknik parametrelerin yüksek değerlerde kullanılmasıyla hasta dozları ve buna bağlı doku hasarları görülme olasılığı giderek artmaktadır. Radyasyon hasarı ile ilgili çalışmalarda rapor edilen hücresel mekanizmaların başında, apoptozis ve hücre içi reaktif oksijen türleri (Reactive Oxygen Species, ROS) oluşumu gelmektedir. Apoptozis, radyoterapi uygulamalarında tümörü yok etmede hedeflenen bir sonuç iken tanısal amaçlı düşük doz uygulamalarda doku hasarını arttırıcı istenmeyen bir sonuçtur. Tanı ve tedavi amacıyla kullanılan radyasyonun, farklı dokular üzerinde erken ve geç etkileri bulunmaktadır. Düşük doz iyonize radyasyonun hücresel düzeyde etkileri, hangi moleküller ve/veya sinyal ileti yolakları üzerinden oluştuğu konusunda çok sayıda araştırma olmasına rağmen henüz tam olarak açıklanamamıştır. Radyasyon hasarlarına ait moleküler düzeyde yapılan çalışmalar, oluşabilecek hasarların erken düzeyde belirlenmesi ve sonrasında önleyici tedavilerin planlanabilmesi açısından çok önemlidir. Bu derleme, radyasyonun hücrede farklı sinyal ileti yolakları ve moleküller üzerinden yaptığı etkileri güncel literatüre bağlı olarak değerlendirmeyi amaçlamıştır. Anahtar kelimeler: Radyasyon; hücre; doku hasarı; apoptozis; reaktif oksijen türleri.

\begin{abstract}
The ionizing radiation imaging methods play an important role in the early diagnosis and treatment of diseases. In diagnosis and treatment, there is the possibility of radiation-induced damage to the patient despite the radiation dose being kept as low as possible and radiation precautions being taken. Therefore, low and/or high dose radiation applications have effects on cell by activating biochemical and molecular signaling pathways. The frequency of applications involving radiation and the use of technical parameters at higher values have led to increase in patient doses. In the studies reporting radiation damage, apoptosis and formation of intracellular reactive oxygen species (ROS) occur at the beginning of cellular mechanisms. Apoptosis is an intent to destroy the tumor in radiotherapy applications, but is undesirable in diagnostic low dose applications. Analysis methods at the molecular level are very important to explain the possible early and late effects of radiation on different tissues. Although there is a lot of research into the effects of low dose radiation on the cellular level, what molecules and / or signaling pathways are involved, it is not yet fully understood. In this review, the effects of radiation on different cellular mechanisms have been evaluated based on the current literature.

Keywords: Radiation; cell; tissue damage; apoptosis; reactive oxygen species.
\end{abstract}

\section{GİRIS}

Radyasyon, elektromanyetik dalgalar veya parçacıklar biçimindeki enerjinin aktarımıdır. X ışınları ve $\gamma$ ışınları gibi yüksek enerjiye sahip elektromanyetik radyasyonlar, karşıllaştı̆̆ madde üzerinde kimyasal bağları kırabilecek etkiye sahiptir. Bu tip iyonlaştırıcı radyasyonun canlılar üzerinde zararlı etkileri olmasına rağmen $X$ ve $\gamma$ ışınları hastalıkların tanı ve tedavisinde sıklıkla kullanılmaktadır (1).

Canlıların temel yapı taşı olan hücreler, vücudumuzda çok farklı yapılarda ve fonksiyonlarda bulunurlar. Hücre hem kendi içinde hem de başka hücreler ile sürekli iletişim içinde bulunarak yaşamsal faaliyetleri sağlıklı bir şekilde sürdürür. Hücre içinde gerçekleşen fizyolojik ve patolojik olaylar çeşitli sinyal ileti yolakları ve bu yolaklarda görev alan çeşitli moleküller tarafından gerçekleşir. Hücreyi

Sorumlu Yazar / Corresponding Author: Yaşar Aysun MANISALIGIL, aysun.manisaligil@deu.edu.tr

Geliş Tarihi / Received: 05.09.2018 Kabul Tarihi/Accepted: 25.10.2018

Bu çalışma, II. Uluslararası Katılımlı Radyasyondan Korunma Kongresi’nde (23-25 Kasım 2017, Ankara) sözlü bildiri olarak sunulmuştur. 
oluşturan moleküller farklı yapılarda bulunurlar. Bunlar proteinler, lipidler, karbonhidratlar, DNA ve RNA molekülleridir. DNA yapısında bulunan genler aracılığı ile bu moleküllerin sentezlenmesi de hücre içinde gerçekleşir. İyonize radyasyona maruz kalan hücrelerde etkilenme şekline bağl1 olarak farklı moleküler ve sinyal ileti yolakları üzerinden etkiler meydana gelir (2). Bu moleküler değişiklikler, genel olarak çift iplik kırılmaları (Double Strand Breaks, DSB), kromozom anomalileri, mikronükleus (MN) ve nükleoplazmik köprüler (Nucleoplasmic Bridges, NPB) frekansları ve/veya strese duyarlı genlerin upregülasyonu ile saptanan genomik instabiliteye neden olur (3).

Bir radyolojik incelemede, örneğin bir bilgisayarlı tomografi (BT) çekimi sonrası hastanın aldığı radyasyon miktarından dolayı doku ve hücrelerinin ne kadar etkilendiği hep bir soru işaretidir. Bunun yanı sıra bu uygulama sonrasında meydana gelen hasarın kendiliğinden ya da dışarıdan bir tedavi ile iyileşip iyileşemeyeceği ve olası hasarın öncesinde yapılacak tedavi ile önlenebilmesi de yanıt bekleyen sorular arasındadır. Bu soruları yanıtlamayı hedefleyen pek çok çalışma her geçen gün literatüre girmektedir. DNA hasarı ve onarım mekanizmaları, hücre içi sinyal yolaklarını konu alan çok sayıda literatür bulunmasına rağmen; çok az sayıda biyobelirteç klinik ortamda kullanılmaktadır (4). Biyobelirteçlerin klinik uygulamaya girmesi, radyasyonun biyolojik etkileri azaltmada önemli katkı sağlayacaktır. Bu makalenin amacı, radyasyonun hücrede farklı sinyal ileti yolakları ve moleküller üzerinden yaptığı etkileri güncel literatüre bağlı olarak değerlendirmektir.

\section{RADYASYONUN ETKIILERİ VE RADYASYON DOZU}

İyonize radyasyonun etkileri sitokastik ve deterministik etkiler olarak iki farklı şekilde oluşabilir. Sitokastik etkiler, alınan dozdan bağımsız, çok düşük dozlarda bile ortaya çıkabilen, ne zaman ve ne şekilde olacağı öngörülemeyen etkilerdir. Deterministik etkiler ise yüksek doz maruziyetlerinde oluşan aniden ortaya çıkabilen ve organizmada büyük hasarlara neden olabilecek sonuçlar meydana getirir.

Canlıların maruz kaldıkları dozlar; çevresel, planlanmış (tıbbi 1şınlamalar) ve kaza durumunda olmak üzere üç farklı tipte gruplandırılır. İyonlaştırıcı radyasyon maruziyetinin yönetimi ve kontrolü, deterministik etkilerin oluşmaması ve sitokastik etkilerin oluşturabileceği risklerin en az düzeyde görülebilmesidir. Coğrafik farklılıklar olsa da toplumun aldığ y1llık radyasyon dozu Uluslararası Radyasyondan Korunma Komitesi (International Commission on Radiological Protection, ICRP) tarafindan $1 \mathrm{mSv}$ olarak belirlenirken yaban hayat için bir doz belirlenmemiştir (5). Japonya' daki atom bombası sonrasında yapılan epidemiyolojik çalışmalardan elde edilen veriler, radyasyon maruziyeti ile karsinojenez arasındaki nedensel ilişki hakkında önemli kanıtlar sağlamıştır (6). Ancak düşük dozlar için doz ve kanser insidansı arasındaki nedensellik üzerinde halen tartışmalar devam etmektedir (7).

\section{RADYASYONUN HÜCRE İLE ETKİLEŞMESI}

İyonize radyasyon hücreyi iki şekilde etkiler. Hücreyi oluşturan atomik yapıları bozarak kimyasal veya biyolojik değişiklikler meydana getiren direkt etki ve suyun hidrolizi sonucu oluşan reaktif oksijen türleri (Reactive Oxygen Species, ROS) ile nükleik asitler, protein ve lipidlerin yapısının bozulması ile meydana gelen indirekt etkidir. Radyasyona bağlı direkt ve indirekt etkiler; hasarın giderilmesi için çeşitli biyokimyasal ve moleküler sinyal yolaklarını aktive eder, kalıcı fizyolojik değişiklikler meydana getirebilir ve hücre ölümüne neden olabilir (8). Hücrenin hangi moleküller ve hangi mekanizmalar üzerinden etkilendiğini bilmediğimiz için stokastik etkilerin ne zaman ve ne şekilde ortaya çıkacağını öngöremeyiz. Radyasyon maruziyetine bağlı hasar, ışınlanmış hücrelerde meydana gelen kararsızlığın ve bu hücrelerin ışınlanmamış hücreler ile etkileşiminin bozulması ile oluşmaktadır $(1,9,10)$.

\section{RADYASYON VE HÜCRE DÖNGÜSÜ}

Hücrenin bölünmeye başlaması ve onu izleyen bir sonraki bölünme aşamasına kadar geçen süreç hücre döngüsü olarak adlandırılır. Hücre bölünmesi esas olarak DNA replikasyonu ve sonrasında kromozomların iki ayr1 hücreye ayrılması ile karakterize edilen iki ardışık süreçten oluşur. Başlangıçta hücre bölünmesi mitoz ve mitoza hazırlık aşaması olan interfaz olarak iki aşamada ele alınmıştır. Daha sonraları mitozun profaz, metafaz, anafaz, telofaz aşamaları ve interfazın da G1, S, G2 fazlarını içerdiği gösterilmiştir (Şekil 1). Mitoz sonrasında hücre bölünmeye devam etmeyecekse G0 fazına geçerek fonksiyonlarını sürdürmeye devam eder. İnsan vücudundaki büyümeyen ve çoğalmayan hücrelerin büyük bölümü bu fazda bulunmaktadır. Eğer hücrenin bölünme süreci devam edecekse hücre büyümesi ve DNA sentezine hazırlık aşaması olan G1 fazına geçer. S fazı hücrenin DNA sentezinin yapıldığı, G2 fazı da mitoza hazırlık aşamasını içeren fazlardır (11).

İnsandaki hücre döngüsü, hücre tipine göre farkl1lık göstermekle birlikte yaklaşık 24 saattir. Hücreler, hücre döngüsünün herhangi bir aşamasında radyasyona maruz kalabilirler ve o anda bir dokudaki her hücre, döngünün farklı zamanlarında bulunabilir. $\mathrm{Bu}$ nedenle daha hızlı bölünen hücrelerin oluşturduğu dokular radyasyondan daha fazla etkilenir. Hücreler G0/G1 fazları ve mitoz sırasında radyasyona maruz kaldığında, kromozomal fragmanların yanlış düzenlenmesi nedeni ile kromozom aberasyonları meydana gelebilir $(12,13)$.

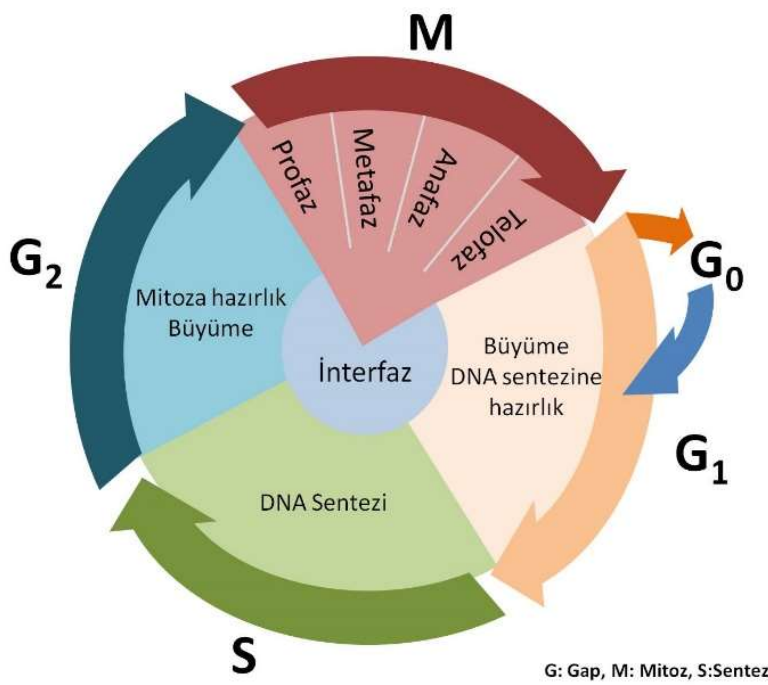

Şekil 1. Hücre döngüsü

\section{RADYASYON VE KROMOZOM}

Hücreler mitoz sırasında iyonize radyasyona maruz kaldığında, anstabil disentrik kromozom frekansı artar ve zaman geçtikçe azalarak normal haline döner. Radyasyon kazalarından hemen sonra disentrik kromozom analizi (Discentric Chromosome Analysis, DCA) ile maruz kalınan doz tahmini yapılabilir. İyonize radyasyona maruz kalan hücrelerde; translokasyon, ring kromozom ve asimetrik kromozom değişimi gibi kromozom anomalilerinin görülme siklığ 1 , disentrik kromozom ile benzerdir. Translokasyonların değişmeden aynı şekilde sonraki hücrelere aktarılması nedeni ile translokasyon skorlaması retrospektif doz belirlenmesi için biyobelirteç olarak önerilmektedir (12-14).

\section{RADYASYON VE DNA}

İyonize radyasyon, hücrelerde DNA hasarına yol açarak hücrenin ölümüne neden olur (15). İyonize radyasyon doğrudan ve/veya dolaylı olarak reaktif serbest radikal üretimi ile DNA üzerinde çeşitli etkiler oluşturabilir. Bu etkiler, DNA'da tek iplik veya çift 
iplik kırılmaları, DNA baz değişiklikleri ya da kayıpları DNADNA çapraz bağlantılar ve 1sı ve/veya alkali hassas bölgelerin oluşmasıdır (16-18). Genomik instabilite olarak tanımlanan bu değişikliklerin; kanser oluşması, apoptozis ve ROS oluşumu gibi hücresel mekanizmaları aktive ettiği çalışmalarla gösterilmiştir $(7,18)$.

\section{RADYASYON VE MOLEKÜLLER}

Günümüze kadar hücrede sadece çekirdeğin radyasyona duyarlı olduğu ve hücrenin geri kalanının radyasyondan etkilenmediği fikri yaygındı. Hücre içi molekülleri hedefleyen çalışmaların artması ile sinyal mekanizmalarını göz önünde bulunduran ve zaman içinde radyasyona karşı hücre yanıtının farklı düzeylerde ortaya çıkabileceğini savunan yeni görüşler ortaya çıkmıştır $(2,19)$. Hem biyolojik dozimetre olabilecek hem de radyoterapi tedavilerinin etkinliğini arttırabilmek için radyasyonun hücrede etkilediği sinyal ileti yolakları ve bu yolaklarda rol alan proteinleri hedefleyen çalışmaların sayısı da giderek artmaktadır. Radyasyon, hücrede çoğunlukla sitotoksik ve sitoprotektif sinyal ileti yolakları üzerinden etki gösterir. Bu sinyal ileti yolakları proproliferatif Ras/Raf/MEK/ERK-MAPK yolağı ve antiapoptotik PI3K-AKT yolağıdır (20). İyonize radyasyona maruz kalmış hücrelerde; 1şınlama sonrasındaki birkaç günde protein ekspresyonunu düzenleyen, hücresel stresi regüle eden p53, NF- $\mathrm{B}$, ERK gibi moleküllerin arttığı çeşitli çalışmalarla gösterilmiştir (21,22). Laiakis ve ark. (23)'nın radyoterapi hastaları üzerine yaptığı çalışmada tedavi öncesi ve sonrasında hastalardan alınan serum örneklerinde; hematolojik parametreler, metabolitler ve iyonlar açısından biyokimyasal analizleri değerlendirilmiştir. Işınlama sonrasındaki sonuçların başlangıç değerlerine göre anlamlı derecede azaldığı gösterilmiştir. Kanser (HeLa, T24, SQ20B) ve kanser olmayan (HFL1, MRC-5, RPE) hücre hatlarında yapılan çalışmada; CDK1 inhibisyonu ile sağlanan radyosensitivite, koloni formasyon analizleriyle belirlenmiştir. CDK1 inhibisyonu ile tümör hücrelerinin radyasyona hassas özellik gösterdiği ancak CDK1 molekülünün etkili inhibisyonuna rağmen koloni formasyon analizlerinde normal fibroblastlar ve epitelyal hücrelerinde etkili olmadığ 1 gözlenmiştir (24).

DNA çift ipliği, histon proteinleri aracılı̆̆ kromatin ve hücre bölünmesi sırasında yoğunlaşarak kromozom halini alır. DNA hasar oluşması sonrasında tamir mekanizmasında rol alan proteinler aktif hale geçerek hasar giderilir. Sonrasında histon proteinleri aracılığı ile eski haline dönüşür. Bu nedenle, $\mathrm{H} 2 \mathrm{AX}$ proteinin inaktif hali olan $\gamma-\mathrm{H} 2 \mathrm{AX}$ proteinin, ya da tamir mekanizmasındaki diğer proteinlerin inaktif hallerinin ortamda bulunması DNA molekülünün hasar gördüğünün göstergesidir (15). İki farklı hücre kültürü ortamında yapılan bir çalışmada, TGF- $\beta$ sinyalinin inaktif hale gelmesi radyasyona bağlı DNA çift iplik tamir proteinlerinin ekspresyonunu baskıladığı gösterilmiştir. $\mathrm{Bu}$ çalışmanın sonuçları, TGF- $\beta$ inhibisyonun tümörlerde hücrelerin radyosenstivitesini arttırmak için kullanılabileceğini göstermektedir (25).

\section{BIYYOLOJIKK DOZIMETRE}

Biyolojik dozimetre, fiziksel dozimetrelerin kullanılamadığ 1 radyolojik ve nükleer kazalar sonrasında radyasyona maruz kalmış bireyler tarafinda soğurulan dozların tahmininde önemli bir rol oynamaktadır. Kromozom aberasyonu ile ilgili sitogenetik çalışmalar, maruz kalınan radyasyon dozu tahmininde bir biyolojik yöntem olarak kullanılabileceği ilk olarak 1964 yılında öne sürülmüştür. Radyasyon dozunun kısa sürede ve doğru tahmin edilebilmesi, oluşabilecek deterministik ve stokastik etkiler öngörülerek uygun tedavi yöntemlerinin belirlenmesi için çok büyük bir öneme sahiptir.

Radyasyona maruz kalmış kişilerin periferik kan lenfositleri içindeki disentrik kromozom oluşmasının, spesifik ve doza bağımlı olduğu rapor edilmiştir. Günümüzde DCA uzun yıllardır iyonize radyasyon dozunu tahmin etmede "altın standart" olarak kullanılmaktadır $(15,26,27)$. DCA, radyasyon dozlarını tahmin etmek için evrensel kabul görmüş ve doğru bir yöntem olmasına rağmen; hücre kültürünün hazırlanması için uzun zaman gereksinimi, sonuçların analizi için bu konuda deneyimli kişilere ihtiyaç duyulması ve düşük doz maruziyetlerindeki hassasiyetin az olması nedeniyle triyaj için hızlı ve pratik değildir $(28,29)$. DCA analizinin yanı sıra kullanılan yöntemler; metafaz analizi, G-bantlama, prematüre kromozom yoğunlaşması (Premature Chromosome Condensation, PCC), floresan in situ hibridizasyon (FISH), lenfosit kinetiği, sitokin bloke mikronükleus analizi (Cytokine Blocked Micronucleus CBMN), $\gamma$-H2AX analizi ve OMICS bilimlerdir (proteomics, transcriptomics ve metabolomics) $(26,27,30)$.

\section{SONUÇ}

İyonize radyasyona maruz kalan her canlı organizmada farklı doku ve hücre tipindeki etkilenmeler, çeşitli şekillerde ortaya çıkabilir. Bu konuda yapılacak çalışmalarla belirlenen moleküller üzerinden etkilenen hücresel mekanizmalara göre özel tedaviler geliştirilebilir. Bu tedaviler radyasyon kazaları sonrasında maruz kalan kişilere uygulanabileceği gibi, tıbbi işınlamalar sonrasında hastalarda oluşabilecek etkileri de en aza indirmede de kullanılabilecektir. Bununla birlikte radyasyon hasarında etkilenen sinyal ileti yolaklarının ve bu yolaklarda rol oynayan moleküllerin belirlenmesi, günümüzde kullanılan biyolojik dozimetre yöntemlerine de katkı sağlayacaktır.

\section{KAYNAKLAR}

1. Cho YH, Kim SY, Woo HD, Kim YJ, Ha SW, Chung HW. Delayed numerical chromosome aberrations in human fibroblasts by low dose of radiation. Int J Environ Res Public Health. 2015;12(12):15162-72.

2. Pouget JP, Georgakilas AG, Ravanat JL. Targeted and offtarget (bystander and abscopal) effects of radiation therapy: Redox mechanisms and risk/benefit analysis. Antioxid Redox Signal. 2018;29(15):1447-87.

3. Shimura N, Kojima S. The lowest radiation dose having molecular changes in the living body. Dose-Response. 2018;16(2):1-17.

4. Bibault JE, Fumagalli I, Ferte C, Chargari C, Soria JC, Deutsch E. Personalized radiation therapy and biomarkerdriven treatment strategies: A systematic review. Cancer Metastasis Rev. 2013;32(3-4):479-92.

5. Vandenhove H, Bradshaw C, Beresford NA, Vives IBJ, Real A, Garnier-Laplace J. ALLIANCE perspectives on integration of humans and the environment into the system of radiological protection. Ann ICRP. 2018;47(3-4):285-97.

6. Ozasa K, Shimizu Y, Suyama A, Kasagi F, Soda M, Grant EJ, et al. Studies of the mortality of atomic bomb survivors, report 14, 1950-2003: An overview of cancer and noncancer diseases. Radiat Res. 2012;177(3):229-43.

7. Mavragani IV, Nikitaki Z, Souli MP, Aziz A, Nowsheen S, Aziz K, et al. Complex DNA damage: A route to radiationinduced genomic instability and carcinogenesis. Cancers (Basel). 2017;9(7):pii.E91.

8. Panganiban RA, Snow AL, Day RM. Mechanisms of radiation toxicity in transformed and non-transformed cells. Int J Mol Sci. 2013;14(8):15931-58.

9. Tomita M, Maeda M. Mechanisms and biological importance of photon-induced bystander responses: Do they have an impact on low-dose radiation responses. J Radiat Res. 2015;56(2):205-19.

10. Kadhim M, Salomaa S, Wright E, Hildebrandt G, Belyakov $\mathrm{OV}$, Prise KM, et al. Non-targeted effects of ionising radiation--implications for low dose risk. Mutat Res. 2013;752(2):84-98.

11. Vermeulen K, Van Bockstaele DR, Berneman ZN. The cell cycle: A review of regulation, deregulation and therapeutic targets in cancer. Cell Prolif. 2003;36(3):131-49. 
12. Gregoire E, Roy L, Buard V, Delbos M, Durand V, MartinBodiot $\mathrm{C}$, et al. Twenty years of FISH-based translocation analysis for retrospective ionizing radiation biodosimetry. Int J Radiat Biol. 2018;94(3):248-58.

13. Tello Cajiao JJ, Carante MP, Bernal Rodriguez MA, Ballarini F. Proximity effects in chromosome aberration induction: Dependence on radiation quality, cell type and dose. DNA Repair (Amst). 2018;64:45-52.

14. Romm H, Ainsbury E, Barnard S, Barrios L, Barquinero JF, Beinke $\mathrm{C}$, et al. Automatic scoring of dicentric chromosomes as a tool in large scale radiation accidents. Mutat Res. 2013;756(1-2):174-83.

15. Manivannan B, Kuppusamy T, Venkatesan S, Perumal V. A comparison of estimates of doses to radiotherapy patients obtained with the dicentric chromosome analysis and the gamma-H2AX assay: Relevance to radiation triage. Appl Radiat Isot. 2018;131:1-7.

16. Tewari S, Khan K, Husain N, Rastogi M, Mishra SP, Srivastav AK. Peripheral blood lymphocytes as in vitro model to evaluate genomic instability caused by low dose radiation. Asian Pac J Cancer Prev. 2016;17(4):1773-7.

17. Bulat T, Keta O, Koricanac L, Zakula J, Petrovic I, RisticFira A, et al. Radiation dose determines the method for quantification of DNA double strand breaks. An Acad Bras Cienc. 2016;88(1):127-36.

18. Nikitaki Z, Nikolov V, Mavragani IV, Mladenov E, Mangelis A, Laskaratou DA, et al. Measurement of complex DNA damage induction and repair in human cellular systems after exposure to ionizing radiations of varying linear energy transfer (LET). Free Radic Res. 2016;50(sup1):S64-S78.

19. Pannkuk EL, Laiakis EC, Singh VK, Fornace AJ. Lipidomic signatures of nonhuman primates with radiation-induced hematopoietic syndrome. Sci Rep. 2017;7(1):9777.

20. Bhattacharya P, Shetake NG, Pandey BN, Kumar A. Receptor tyrosine kinase signaling in cancer radiotherapy and its targeting for tumor radiosensitization. Int J Radiat Biol. 2018;94(7):628-44.

21. Levine JH, Lin Y, Elowitz MB. Functional roles of pulsing in genetic circuits. Science. 2013;342(6163):1193-200.

22. Purvis JE, Karhohs KW, Mock C, Batchelor E, Loewer A, Lahav G. p53 dynamics control cell fate. Science. 2012;336(6087):1440-4.

23. Laiakis EC, Pannkuk EL, Chauthe SK, Wang YW, Lian M, Mak TD, et al. A serum small molecule biosignature of radiation exposure from total body irradiated patients. J Proteome Res. 2017;16(10):3805-15.

24. Prevo R, Pirovano G, Puliyadi R, Herbert KJ, RodriguezBerriguete G, O'Docherty A, et al. CDK1 inhibition sensitizes normal cells to DNA damage in a cell cycle dependent manner. Cell Cycle. 2018;17(12):1513-23.

25. Bayin NS, Ma L, Thomas C, Baitalmal R, Sure A, Fansiwala $\mathrm{K}$, et al. Patient-specific screening using high-grade glioma explants to determine potential radiosensitization by a TGFbeta small molecule inhibitor. Neoplasia. 2016;18(12):795805.

26. Abtahi MM, Aghamiri MR, Yadolahi M, Mahmoodzade A. Biological dosimetry method: A probable way for measuring percent depth dose. World Fam Med. 2018;16(1):193-7.

27. Lloyd DC, Edwards AA, Moquet JE, Guerrero-Carbajal YC. The role of cytogenetics in early triage of radiation casualties. Appl Radiat Isot. 2000;52(5):1107-12.

28. Tichy A, Kabacik S, O'Brien G, Pejchal J, Sinkorova Z, Kmochova A, et al. The first in vivo multiparametric comparison of different radiation exposure biomarkers in human blood. Plos One. 2018;13(2):e0193412.

29. Vinnikov VA. Optimizing the microscopy time schedule for chromosomal dosimetry of high-dose and partial-body irradiations. Genome Integr. 2017;8:3.

30. Little JB. Radiation carcinogenesis. Carcinogenesis. 2000;21(3):397-404. 